Stream: Inspiring Critical Thought

2018, Vol 10(1), 1-2

(C) The Author(s), 2018

http://journals.sfu.ca/stream

\title{
Public Sphere(s), Public Narratives, and Counter Public(s): Stu- dent Papers at the 2017 Canadian Communication Association
}

\author{
Nina Duque \\ Département de communication sociale et publique \\ Université du Québec à Montréal \\ Mary Grace Lao \\ Communication \& Culture Program \\ York \& Ryerson Universities \\ Lena A. Hübner \\ École des médias \\ Université du Québec à Montréal \\ Thomas H. Mboa Nkoudou \\ Département d'information et de communication \\ Université Laval
}

It is with enthusiasm that we present this special issue of Stream devoted to the student conference proceedings from the 2017 Canadian Communication Association annual meeting during the Congress for Social Science and Humanities held at Ryerson University. As current graduate students, we understand and appreciate the challenges that graduate students face and having a medium like the annual CCA-ACC conference provides the kind of professionalization that graduate students need to continue a career as academics.

Full credit for the publication of these special proceedings goes to the guest editors, Lena Alexandra Hübner (UQAM) and Thomas Hervé Mboa Nkoudou (Université Laval) and to Sibo Chen and Peter Zuurbier (Simon Fraser University), who ensured a seamless transition from peer review to publication on Stream. We would also like to extend our gratitude to the peer reviewers and copy editors, who, without their expertise, this special issue would not have been possible. Each of the papers presented here is indicative of the diversity of research being employed by emerging scholars across Canada. The contributions of this special issue add to the growing corpus of communication scholarship that has emerged recently. We hope that these papers push readers to consider the current ways in which they use media, how they interrogate online narratives, and how these current structures reinforce privileged voices. We also hope that future graduate students continue to publish these proceedings, to continue the legacy we have started here. 


\section{Sphères Publiques, Discours Publics et Contre-publics: Actes des Communications Étudiantes du Colloque Annuel de l'Asso- ciation Canadienne de Communication 2017}

Ce numéro spécial de la revue Stream se veut un recueil des actes des communications étudiantes du Colloque annuel de l'Association canadienne de communication (ACC) qui s'est tenu au printemps 2017 à l'Université Ryerson dans le cadre du Congrès de la fédération des sciences humaines. En tant qu'étudiantes, nous comprenons les défis auxquels font face les étudiantes de $2 \mathrm{e}$ et $3 \mathrm{e}$ cycles. Ainsi, la conférence annuelle CCA-ACC et la publication de ces actes nous fournissent, à nous jeunes chercheurs et chercheuses, de riches apprentissages qui nous permettant de faire les premiers pas dans une carrière universitaire.

Pour cette 2e édition, ce sont Lena Alexandra Hübner (UQAM) et Thomas Hervé Mboa Nkoudou (Université Laval), respectivement rédactrice et rédacteur en chef invitées, avec l'aide de Sibo Chen et Peter Zuurbier (Université Simon Fraser), qui ont habilement coordonné la publication de ces actes. Nous tenons également à remercier tous ceux et toutes celles ayant participé à l'évaluation, la révision et l'édition de ce numéro. Les articles ci-présentés contribuent à la diversité de la recherche universitaire émergente à travers le Canada. Nous espérons que ces textes inciteront les lecteurs et lectrices à réfléchir sur leurs usages et pratiques médiatiques, tout en interrogeant les récits proposés, de même que les structures sociales actuelles et le renforcement des voix de groupes privilégiés. Nous espérons finalement que les futures étudiantes des cycles supérieurs continueront de publier ces actes, afin de poursuivre l'héritage et la vision entamée en 2016. 